\title{
A Deferred Meaning of Home in Claude McKay's Novel Home to Harlem
}

\author{
Mike Wijaya Saragih \\ English Department, Faculty of Letters, Universitas Kristen Indonesia, Jakarta, Indonesia \\ mike.wijaya@uki.ac.id
}

\begin{abstract}
Taking a title of his first novel Home to Harlem (1928), Claude McKay as the implied author seems to bring the perception of his readers to a standpoint saying that Harlem was a final destination for blacks in the early 20th century, the time setting of the novel. Paradoxically, the novel gives a twisted ending by letting both of the main black characters in the novel, Jake and Ray, leave Harlem because of different reasons. This article aims to show a deferred meaning of "Home to Harlem" in the novel as well as to find the hidden aim in the novel. This research will use Derrida's theory about deconstruction and differance concept. The result shows that the text seems to deconstruct a myth about Harlem as the mecca of the New Negro. The meaning of home in the novel has deferred into a space inhabited by a familiar in which one can find needs of physical, intellectual, mental, and emotional security. A decision to leave Harlem chosen by both of main characters in the novel is a symbol that Harlem cannot be the best representative of African American's home enabling to meet all of blacks' needs of racial equality in the early twentieth century.
\end{abstract}

Keywords: deconstruction, deferred meaning, Harlem, home

\section{INTRODUCTION}

Some forms of discrimination that occurred eventually culminated into anxiety and desire of black intellectuals and social activists to fight for equal rights as fellow Americans. In 1909, a group of AfricanAmerican political activists and a group of human rights fighters (whites) led by a historian and sociologist WEB Bois founded the National Association for the Advancement of Colored People (NAACP), an association that fought for human rights of black society, including African Americans. One of the association's main programs was to gather and encourage African-American artists and writers to work through art and culture with the spirit of carrying out a mission of racial equality. The NAACP finally paid off with the emergence of a glorious and revival of African-American arts and culture among the white community, through literary works (prose and poetry), painting, dance, and jazz music or known as Harlem Renaissance.

The Harlem Renaissance was a form of reverse proof of negative stereotypes that were always imposed on black people. Through works of art and culture, groups of black intellectuals and artists tried to highlight the existence and self pride of black people among the white community. Robert Bone (in Cooper, 1964: 297) adds that this period was "a period of selfdiscovery", meaning that black society formed their new identity as "New Negro" or according to Alain Locke (in Cooper, 1964: 297), it was marked by a new spirit to renew "self-respect and self-dependence". This new identity then gave birth to new confidence and enthusiasm for the black community to keep hoping and fighting for a better life in America.

One of the main themes that were often used as objects of inspiration by Harlem Renaissance's writers was the city of Harlem itself. For black Americans who migrated from the South or the Caribbean, Harlem was seen as the city of dreams, while for intellectuals, Harlem was seen as the Culture Capital, the greatest Negro city in the world, the mecca of the New Negro, and the City of Refuge (Wall, 2016: 45). The assessment of the city of Harlem above then made Harlem as a place that was often referred to a "home" in many literary works in the Harlem Renaissance period. It is interesting to find the paradigm shift of African-American immigrants, from those previously forced to come to America and be treated only as second-class citizens, but then able to see Harlem as a "home" for them.

One of the authors of the Harlem Renaissance that featured Harlem as "home" was Claude McKay (1889-1948). Claude McKay was an African-American prose and poetry writer born in Jamaica as the baptised name Festus Clausdius McKay. He had been known since 1912 through his poems voicing rebellion as well as social criticism for the white community. However, 
from all of the prose he wrote, Home to Harlem became McKay's most famous novel and won the Harmon Gold Award for Literature, a prestigious award for African American art. In addition, Home to Harlem was also known as the first best-selling novel written by African Americans.

As the title suggests, Home to Harlem (1928) is a novel showing the journey of the main character, Jake Browns, to find something he was deemed as "home". Raising the primitive life of the African American proletariat in Harlem in 1914-1919, McKay seemed to present Harlem as a dream city for most AfricanAmericans, including Jake Browns. This novel was increasingly interesting and complex when McKay seemed to hide the meaning behind every place Jake visited and every woman Jake encountered on his journey to find his last "home". The problem in this novel grew even more when Jake met and finally became close friends with the other main character Ray, a Haitian intellectual who had much different social background from Jake. McKay seemed to compare two characters, Jake and Ray, to further deepen the meaning of "home" for the marginalized group.

Regarding Harlem as "home", Lowney (2000) and Rottenberg (2010) also discuss on this topic in their research. For Jake, Harlem is seen as the center of his movement, from and to Harlem (Lowney, 2010: 423) and at the same time as a black community center containing entertainment, fun, and hope for a good life (Rottenberg, 2010: 121). However, Jake's idea is different from Ray. For Ray, Harlem is not considered as a "home", but only a destination (Lowney, 2010: 423). Both studies have an idea that Harlem is African Americans' home, but this research will prove another perspective saying that there is still an implied and hidden meaning the text tries to show us that Harlem cannot be the best representative home for African Americans. Therefore, this article aims to show a deferred meaning of "Home to Harlem" in the novel as well as to find the possible reason why Claude McKay did so in his novel.

\section{HARLEM AS A MYTH OF HOME}

Some existing research and literature have been done to develop the concept of "home" which does not only refer to a physical form of a house. Hollander (in Mallet, 2004: 65) notes that the word "home" in German (heim, ham, heem) comes from the IndoEuropean word "kei" which means lying down and something that is loved. In other words, this word means something like a place to lay someone's head. According to him, the German word for "house", which means a building where people live, or where a family lives, is influenced by the meaning of the word "home".

In addition, Hollander (in Mallet, 2004) also adds that in English, the word "home" comes from the Anglo-Saxon word "ham" which means village, plantation, or urban. Mallet explains in his writing about the concept of "home" which is different from "house" because the concept of "home" does not only talk about a place but also space and interactions that occur in that space. This causes the boundaries of the meaning of "home" become blurred.

Gurney (1990: 26-29) argues that "home" can be seen as an ideological construction created by an individual's emotional experience of where they live. However, Somerville (1992: 530) complements Gurney's opinion of "home" which is not merely a matter of feeling and life experience, but also a construction of cognition and intellectuals in which a person may have the meaning of "home" even though they have no experience or memory about it.

Talking about the concept of "home" is also closely related to a long discussion about "the real and the ideal home" and "the actual and remembered home". In this case, Tucker argues that the meaning of "home" is like a prolonged journey and search:

"the most people spend their lives in search of home, at the gap between the natural home [conceived as the home environment conducive to human existence, i.e. dry land] and the particular ideal home where they would be fully fulfilled...search for a Promised Land...actual home tends to be our approximation of our ideal home, under a given set of constraining circumstances" (in Mallet, 2004:69).

The statement above wants to emphasize the search of "an ideal home" as if waiting for "The Promised Land", as an allusion to a history written in the bible. "Home" becomes a symbol of happiness that must be sought and pursued to have. The context of "The Promised Land" is also closely related to the group of people marginalized by other groups so that the longing for "home" becomes very essential and urgent.

The word "myth" according to Barthes (2012: 217 ) is a communication system that contains a message in it. Myth is not a particular object, concept, or thought, but rather a method of marking "a mode of signification, a form". The word "Harlem" becomes a myth against a place that has a positive connotation in the history of African American ethnic groups in the era of the Harlem Renaissance (1920s-1930s). Harlem becomes a mode of signification conveying "the city of dreams", "the cultural capital", "the greatest Negro city 
in the world", "the Mecca of the New Negro", and "the city of refuge" for African American (Wall, 2016: 45).

The novel Home to Harlem initially shows the position stating Harlem as a myth of home for African Americans, especially for the main character Jake Brown.

He didn't care about the dirty old boat, anyhow. It was taking him back home-that was all he cared about... "Nip me all you wanta, Mister Louse," said Jake. "Roll on, Mister Ship, and stinks all the way as you rolls. Jest take me 'long to Harlem is all I pray. I'm crazy to see again the-brown-skin chippies 'long Lenox Avenue. Oh boy!" (McKay, 1987: 3)

Harlem for Jake is described as something able to move him. His identity as a slave descendant migrating from South makes Harlem as his dream city. It is stated that Jake is an American deserter from the World War I before he decides to be a ship worker. His harsh experience of racial discrimination occured in the South America, in Germany, and in some cities in Europe gives him the prolonged longing to Harlem where he once feels freedom. What Jake cares about is only going home to Harlem. His prolonged longing to Harlem gives him some strength to hold back for all unpleasant things he has to face in his way home. His longing gives him bravery to pay all the cost that might come. It is clearly stated in the text that Jake explicitly names Harlem as his home, his dream city that he believes it is able to give him some pleasure he is longing and looking for. Going to Harlem is the only prayer he has and something makes him crazy.

Besides, Harlem as home is also described in the text as if it is an organic place that can be felt. Speaking of Harlem brings some sensory memory about all the experience occured there. Harlem is shown as something that can be seen, smelled, and felt. "He thrilled to Harlem. His blood was hot. His eyes were alert as he sniffed the street like a hound. Seven Avenue was nice, a little too nice that night" (McKay, 1987:10). It is connected to what Bremer says in his article that Harlem is "fleshly - and embodied in lively colors, tastes, and sounds", and it can give life "life-giving home" (1990: 50). In the article, Bremer associates Harlem as "home" with "sex, food, and breath". Harlem is shown as a place that gives some pleasure to African American. This statement is spoken when Jake firstly arrives in Harlem after his long journey. His ability to see, sniff, and feel Harlem shows that Harlem gives him some good memory that isn't easy to be thrown away. Harlem keeps lots of pleasure, enjoyment and satisfaction.

\section{A DEFERRED MEANING OF HOME}

According to Derrida, languages are set up of units that don't contain inherent meaning. It means that there is no fixed meaning of any languages. Any structure whether in social studies, science or litetrature needs re-thinking from new position to leave demontrativeness to interpretation (Derrida, 1976:81, 158-159). Bertens (2001: 124-127) summarizes Derrida's main arguments into five points. First, language is inherently unreliable. Second, there is no single word. Third, reality determined the shape of our language. Fourth, words are never stable and fixed in time. Fifth, meaning is the product of difference and it is also always subject to a process of deferral. From these points, it is shown that the meaning of words is fluid. There is always found a process of deferral in languages.

Derrida also comes with his theory "deconstruction" as his disagreement to structuralism. Derrida (in Yegen, 2014) disagrees the idea that a text or a communication has an undergoing, unified meaning. According to him, meaning in "deconstruction" is constantly deferred, which can never be in place, or be stable. Deconstruction can be interpreted as a situation that expresses the response of the reader to the text at the point of producing the meaning even if it is confused with other trends. It means taking, undoing or changing, in order to find and show the assumptions behind a text. There might be many interpretations of a text produced by an author.

Derrida then introduces the word 'differance' in order to indicate the relation between signifiers as one of both difference and deferral. If a word's meaning is solely the result of its difference from other words, then the meaning is not an additional thing 'present' in the sign itself. On the contrary, 'meaning' is the perennial play of difference between signifier and signified, a 'slipping from word-to-word' in which each word retains relations to the words that differ from it. Later, language is studied in terms of discourses to get an overall and multi-dimensional aspect of meaning (Garg, Kumar \& Sharma, 2014). Derrida concludes that meaning is the result of difference between sign \& signifier which can also be deferred easily. Therefore, it's impossible to find a stable and fixed meaning as there is always an element of undecidablity in the unstable sign.

Taking the title as Home to Harlem cannot also be concluded easily as the home finding for the main characters in the novel. The idea of deconstruction and differance brings some interpretation to defer the meaning of home itself. At the beginning of the story, it is stated that Harlem becomes the dreamed 
destination for both Jake and Ray. Harlem becomes the place and space as a shelter or abode in which they have their physical security. In Harlem, Jake and Ray are physically secured for there is a condition that makes them comfortable when Blacks have their own freedom to express their identity there. However, the fact says differently. Although they are both close friends and feel happy to know each other, it isn't enough to make them feel that they are mentally secured. The text shows that their friendship finally makes them know that they are very different and cannot be together any longer. Ray as a Haitian intellectual judges that Jake and other black people in Harlem are more inferior than he is. Although they are alike as blacks, Ray puts himself better in all conditions rather than Jake. His educational background forces him to separate between savaged and civilized lives. The more he knows the African American's life style in Harlem, the more he feels alienated. His way of life is far different from the people there and it makes him feel mentally and intellectually unsecured.

Ray finally feels that Harlem is not his home. His different social background from Jake and other black people gives him awareness that Harlem is not as good as what he thinks before. Born as a part of African cannot make Ray able to acclaim that he and Jake are the same. The fact is that Ray judges Harlem as a savaged place. "Harlem is too savage about some things. Bulldyker," the waiter [Ray] stressed with a sneer. His educational background forced him to make a distance between him and the black people in Harlem. "I am getting sick of it," Ray said. "It's a crazy, clattering, nerve-shattering life. I think I'll fall down for good." (McKay, 1987:239). This statement shows that Ray feels allienated being in Harlem. The use of some negative words to identify Harlem shows his position as if a colonizer who gives a negative labelling to black people. The statement "I think I'll fall down for goods" can also be read as his negative claim to Harlem. Instead of saying that Harlem is his home giving a good fortune for his life, Ray claims that staying longer in Harlem can be dangerous for him for he can be badly influenced by the way of people's lives in Harlem.

He [Ray] was afraid that some day the urge of the flesh and the mind's hankering after the pattern of respectable comfort might chase his high dreams out of him and deflate him to the contented animal that was a Harlem nigger strutting his stuff. (McKay, 1987:264)

From the statement above, it can be seen that Ray experiences an inner conflict because he himself sees and realizes that the people's lifestyle in Harlem can ruin his dream of a better future. Life in Harlem, for Ray, is seen as a physical life controlled by lust. This then makes Ray consciously wants to rid himself of black life in Harlem. In this case, Ray indirectly makes borderism between himself and the free life of Harlem.

The phrase "the contented animal" refers to Harlem black man — including Jake. The level of male sexual satisfaction is analogous to the level of satisfaction of an animal that tends not to be able to control its own libido. Giving an "animal" identity to a black Harlem man becomes a practice of intra-racial racism which can be read as an attempt to differentiate or limit the social class between Ray and Jake. Consciously, Jake and other black men are positioned in groups that are uncivilized, whereas Ray is positioned in a civilized group. Ray shows that he is alienated in Harlem and finds that Harlem is not his place or home he dreams of.

Ray finally chooses to leave Harlem and continue his journey to find his "real" home. "Ray and Grant had found jobs on a freighter that was going down across the Pacific to Australia and from there to Europe. Ray had reached the point where going any further on the railroad was impossible." (McKay, 1987:265). Instead of choosing one place to be his next home, Ray decides to be a freighter that gives him a chance to see and experience a new challenging life. $\mathrm{He}$ prefers his self actualization to any kind of comfort. The definition of home becomes extended to a space that fulfills someone's desire and self actualization. It cannot be limited to such geographical borders. Being home gives an idea about being in such a physically and mentally comfortable space.

The deferred meaning of home is also found in Jake's character. The novel constructs Jake's identity differently from Ray. Instead of dreaming of a better future, one of Jake's purposes moving to and from Harlem is his desire for women. The presence of women in Jake's life is very significant. His emotional balance is often influenced by the presence of women in his life. Even Jake's decision to leave Harlem and move to Chicago is also caused by his special woman named Felice.

After prolonged waiting for the brown-skinned girl later known as Felice, a prostitute, Jake's life is shown very happy. It is stated that Jake and Felice spend time together having happy life in Harlem. Jake's purpose in life, which still focuses on looking for pleasure and self-satisfaction, makes him feel enough to live only with Felice for long period. The statement "They [Jake and Felice] wove the atmosphere of dreams around them and was lost in it for a week" (McKay, 1987: 314) shows how dependent Jake is on 
Felice. Felice is able to grab Jack's full attention, desire, thought, and time. His emotional comfort is depended on the presence of Felice in his side.

The condition changes, but Felice keeps being a magnet for Jake. In the last part of the story, McKay seems to make a twisted ending by making a love conflict between Jake, Felice, and Zeddy, one of Jake's close friends. As a beautiful prostitute, Felice has some black men who fall in love with her. The fact that Jake is a deserter is only known by few of his close friends, one of whom is Zeddy. However knowing that Felice chooses Jake as his best partner makes Zeddy gets angry and plans a revenge to Jake. When they meet each other accidentally in a club, Zeddy shows his anger by shouting Jake's secret in the club. His jealousy to Jake makes him brave to do something that harms his friend and breaks their friendship. Although Zeddy finally feels regretful for whatever he does to Jake, Jake and Felice decides to leave Harlem.

Felice: “...But all the same, we can't stay in Harlem no longer, for the bulls will sure get you." ... "I been thinking a gitting away from the stinking mess and go on off to see again."

Felice: "Jest le's beat it away from Harlem, daddy. This heah country is good and big enough for us to git lost in. You know Chicago?"

Jake: "Why, le's go to Chicago, then. I hear it's a mahvelous place foh niggers. Chicago, honey."

Felice: "When"

Jake: "This heah very night. Ise ready. Ain't nothing in Harlem holding me, honey. Le's pack.

(McKay, 1987:332-3)

The conversation above shows that Felice can drive Jake in making an important decision. Harlem is a place that Jake dreams of. However, feeling threatened makes him decide to leave Harlem, and being together with his beloved girl makes him feel at home no matter where it is. Jake leaves Harlem because he cannot find any physical and emotional security in Harlem anymore. Felice is a symbol of "home" for Jake, in which he can find peace, pleasure, and emotional comfort. From this explanation, it is shown that a deferred meaning of home is a place in which someone can find a true emotional comfort.

\section{CONCLUSION}

Claude McKay as the implied author tries to deconstruct a myth about Harlem as the mecca of the New Negro. The meaning of home in Claude McKay' Home to Harlem has a deferred meaning. Home is not only a place as a shelter or abode that gives physical security, but also a space inhabited by a familiarpeople, things and belongings - in which one can find needs of physical, mental, intellectual and emotional security. It gives lots of love, warmth, joy, and peace. There can also be an inner connection within the people that keep us away from feeling threatened.

Through the novel, McKay seems to show a hidden aim. He seems to emphasize that Harlem isn't the best representative of African American's home enabling to meet all of blacks' needs of racial equality as well as their physical, mental, intellectual, and emotional freedom. It was then proven in the early twentieth century, the next two decades when Harlem Renaissance ended and racial equality is still a big issue faced by African Americans till some decades ahead.

\section{REFERENCES}

[1] Barthes, Roland., 2012. Mythologies. Diterjemahkan oleh Richard Howard/Annette Lavers. New York: Hill and Wang.

[2] Bertens, J.W., 2001. Literary Theory: Basics. London, GBR: Routledge.

[3] Bremer, Sidney H., 1990. Home in Harlem, New York: Lessons from the Harlem Renaissance Writers. PMLA, 105(1), 47-56. doi:1. Retrieved from http://www.jstor.org/stable/462342 doi:1

[4] Cooper, Wayne., 1964. Claude McKay and the New Negro of the 1920's. Phylon, 25(3), 297-306. Retrieved

from http://www.jstor.org/stable/40027037.

[5] Derrida, J., 1976. Of Grammatology, Trans. Gayatri Chakravorty Spivak. Baltimore: Johns Hopkins University Press.

[6] Garg, N., Kumar, S., \& Sharma, V., 2014. Concepts of Difference and Differance: A Comparative Study of Saussure and Derrida. Language in India, 14, 141-147.

[7] Gurney, C. 1990. The meaning of home in the decade of owner-occupation: towards an experiential perspective. Working Paper 88. School of Advanced Urban Studies, University of Bristol.

[8] Lowney, J., 2000. Haiti and Black Transnationalism: Remapping the Migrant Geography of Home to Harlem. African American 
Review, 34(3), 413-429. doi:1. Retrieved from http://www.jstor.org/stable/2901381 doi:1

[9] Mallet, S., 2004. Understanding Home: A Critical Review of Literature. The Sosiological Review, 52(1), 62-89.

[10] McKay, Claude., 1987. Home to Harlem. Boston: Northeastern University Press.

[11] Rottenberg, C., 2010. Writing from the Margins of the Margins: Michael Gold's Jews Without Money and Claude McKay's Home to Harlem. MELUS, 35(1), 119-140. Retrieved from http://www.jstor.org/stable/40587213
[12] Somerville, P., 1992, 'Homelessness and the Meaning of Home: Rooflessness and Rootlessness?' International Journal of Urban and Regional Research, 16 (4), 529-539.

[13] Sowell, Thomas., 1981. Ethnic America. New York: Basic Books, Inc.

[14] Yegen, Qeren., 2014. Derrida and Language: Deconstruction. International Journal of Linguistics, 6(2), 48-61.

[15] Wall, Cheryl A., 2016. The Harlem Renaissance: A Very Short Introduction. New York: Oxford University Press. 